REFLECTIONS:

NEUROLOGY AND

THE HUMANITIES

Section Editor

Anne W. McCammon,

MD, FAAN

\title{
The Ghost of Gehrig
}

I have phobias. I am afraid of flying. I despise insects. But I do not suffer fear of ghosts. At my age, I still recall my mother's words after childhood nightmares: "Be afraid of the living, not of the dead." So I was oblivious when I met the Ghost of Gehrig for the first time as an intern during ICU rounds. He had possessed an elderly man, wasted his muscles, immobilized his body, and sucked away his breathing and speech. I ignored Gehrig's Ghost on our first encounter. This man was old, and the thought that we are all mortal was a common, if superficial, way to cope.

A year later, at the start of neurology residency, Gehrig's Ghost and I met for a second time. This old gentleman was lying in bed speechless, his muscles gone, and his breathing mechanically assisted. Yet, Gehrig's Ghost could not prevent the man from talking with his eyes. They spoke about resignation and serene acceptance of the next step of the journey. In the turmoil of treating strokes and seizures during call night, I did not realize that Gehrig's Ghost was beginning to haunt me. He accompanied me home and played a prank as I tried to sleep. My muscles twitched, my breathing rate increased, the weight of the world sat on my chest, and there was doom and gloom all over the universe. I performed a full motor examination on myself daily. I parachuted into our neuromuscular clinic for a full examination. Unrevealing. False alarm.

A few months later, the Ghost of Gehrig appeared to me again in the form of a young veteran. This time, I could not ignore him. He was sitting right in front of me, playing with my feelings, as if saying, "I am not going anywhere; I am right here." Though I was spared from participation in the diagnostic workup, I could not help looking into the records for clinical and electrodiagnostic evidence of the Ghost. And there it was in the EMG report, in the form of fibrillations, fasciculations, and big, angry, nasty, denervated units. In an instant, I felt the muscle twitching, the inability to breathe, and the sense of doom. This time, however, my muscles twitched for days, and I could not do anything about it. I was sure the possession would become apparent in 6 months. Twelve months later, with the twitches gone, I was reassured by the realization of another false alarm.

As physicians, we are used to dealing with the problems of our patients, but we can have difficulty confronting our own. I figured that enrolling in neuromuscular fellowship training provided an opportunity to engage my own fear of the Ghost of Gehrig. For the next year, in ALS Clinic, I met him on a monthly basis. The Ghost did not spare young or old, man or woman, rich or poor. He just played his game, and I played mine. I tried to fight the Ghost, and he just fought back, unrelenting. My muscles twitched for days before the clinic, and would not stop until days after. The Ghost drained the energy from physicians, nurses, assistants, technicians, and receptionists alike. Silence reigned in the neuromuscular fellow work room. Presentations to attending physicians were grim and straightforward. It was not rare to see a fellow, nurse, or technician take a moment in an empty exam room to wipe a few tears. Patient encounters were long and profound. It took us days to recover, and 4 weeks later we were back at it again.

After a full year of monthly battles, I felt ready to tackle the Ghost of Gehrig on my own. We met around the fall of my first year in practice but I did not see him coming. I went into that exam room ready to diagnose routine carpal tunnel syndrome. And there was the possessed. With his neck drop, flail arms, spastic speech, and terrible fasciculation. He knew; he just needed confirmation of his disease. In a moment of despair, the patient revealed a plan to end his own life. I wheeled him to a nearby religious hospital, ironically thinking about the days in which priests could simply exorcise ghosts. Not this Ghost, though.

Surprisingly, this was the first time that my muscles did not twitch. In fact, a few weeks later I performed the full diagnosis of a man with possible ALS. I dreaded the visit for days, but again, I had experienced no twitching. The diagnostic workup was completed, and the bad news was relayed to the patient and his family. A full plan was devised, consistent with the wishes of the patient and current standards of care. No twitching after the encounter. Had I finally beaten Gehrig's Ghost?

I recently saw the Ghost at Fenway Park, when the Yankees visited the Red Sox. This time he was not a dismantler of bodies, but an idol. As the Bronx Bombers blasted baseballs over the Green Monster, a good percentage of us New York fans who dared to reveal

Listen to Dr. Almodovar read this essay, available exclusively on Neurology ${ }^{\circledR}$ for the $\operatorname{iPad}^{\circledR}$. 
ourselves to New Englanders wore the pinstripes with the big number 4 of the Iron Horse. A few days later, while reading Eleanor Gehrig's memoir, I got a glimpse of Gehrig the man, rather than his malady. Mrs. Gehrig devoted only 1 chapter to the disease. The rest of the book is about her life with this great baseball player, who happened to suffer from ALS.
Learning about how the rest of the world sees Lou Gehrig has helped me cope with my reaction when encountering ALS. Every once in a while I will feel a muscle twitch. Luckily I am able to ignore it as purely physiologic. On a recent visit to the Baseball Hall of Fame in Cooperstown, I gathered the courage to buy the Gehrig shirt. I have not been able to wear it, yet. It is just a matter of time. The Ghost of Gehrig is not my nemesis anymore. 


\section{Neurology}

The Ghost of Gehrig

Jorge L. Almodovar

Neurology 2013;80;223-224

DOI 10.1212/WNL.0b013e31827b92f4

\section{This information is current as of January 7, 2013}

\section{Updated Information \& Services}

\section{Subspecialty Collections}

Permissions \& Licensing

\section{Reprints}

including high resolution figures, can be found at: http://n.neurology.org/content/80/2/223.full

This article, along with others on similar topics, appears in the following collection(s):

\section{Amyotrophic lateral sclerosis}

http://n.neurology.org/cgi/collection/amyotrophic_lateral_sclerosis_

Information about reproducing this article in parts (figures,tables) or in its entirety can be found online at:

http://www.neurology.org/about/about_the_journal\#permissions

Information about ordering reprints can be found online:

http://n.neurology.org/subscribers/advertise

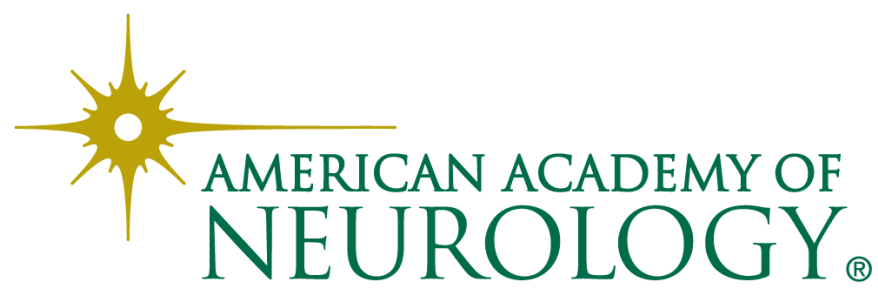

